\title{
The Validity and Reliability of the Online Cooperative Learning Attitude Scales in the Indonesian Language
}

\author{
Elisabeth Rukmini ${ }^{*}$, Arya Susila Nugraha ${ }^{2}$, Hanna Angelina ${ }^{2}$, Dara Aprilia Christianty ${ }^{3}$ \\ ${ }^{1}$ Department of Civil Engineering \& Center for Urban Studies, Universitas Pembangunan Jaya, \\ Tangerang Selatan, Indonesia \\ ${ }^{2}$ Department of Chemistry Education, Universitas Sanata Dharma, Yogyakarta, Indonesia \\ ${ }^{3}$ Department of Psychology, Universitas Katolik Indonesia Atma Jaya, Jakarta, Indonesia \\ *Corresponding author: elisabeth.rukmini@upj.ac.id
}

Abstract— Interactive online learning requires students' cooperation. Online cooperative learning focuses on learning activities on group cohesiveness to achieve the highest cognitive level. Students can improve their teamwork skills, problemsolving skills, social skills, self-confidence, academic success, and metacognition levels through online cooperative learning activities. The Online Cooperative Learning Attitude Scales (OCLAS) scale is a tool to measure students' attitudes towards online cooperative learning. Education in Indonesia uses Indonesian as the language of instruction. Therefore, the adaptation of measurement tools such as OCLAS into the Indonesian language is crucial. This study aimed to adapt OCLAS into Indonesian by translating the original OCLAS into the Indonesian language and determining the instrument's validity and reliability. The OCLAS has three main components: positive interdependence, individual accountability, and group processing for equal individual contribution. The original version contained 17 statements with responses using a Likert scale of five and seven points. We validated the OCLAS using the item-correlation method. The reliability was measured using the Cronbach's Alpha method, which is useful for measuring internal consistency. The original OCLAS was translated into the Indonesian Language. A language center in a prominent university performed the verification of forward and backward translation of the Indonesian OCLAS. The Indonesian-OCLA was distributed to 59 students at a private university from the pharmacy and non-pharmacy study programs and 275 high school students. The validation results showed seven invalid items for pharmacy students, five invalid items for non-pharmacy students, and six invalid items for high school students. The IndonesianOCLAS has Cronbach's Alpha reliability with a value of 0.711 for pharmacy students, 0.791 for non-pharmaceutical students, and 0.702 for high school students. This study showed that ten out of 17 statements had good validity, and they were reliable. Therefore, we recommended the usage of the Indonesian-OCLAS toward high school and college students.

Keywords- attitude, collaboration, cooperative, measurement, online learning, student-centered learning.

\section{INTRODUCTION}

Online learning has become a habit since the 2020 Pandemic. However, we need the driving factors that make the online learning experience more meaningful. Qualitatively, researchers show that the urge to do better online learning continues [1]. Students feel that a variety of innovative and collaborative learning approaches will encourage student involvement in the study [1]. Studies in Indonesia [2] and Bangladesh [3] showed complaints against online learning from teachers and students. Students and teachers want cooperative learning. However, it has not been achieved; previous research showed that online learning only showed mediocre collaborative and cooperative learning achievement [3]. Meanwhile, research at the University of Jambi [2] showed that the most respondents $(48 \%)$ felt that the portion of 
self-independent learning is only 1-2 times a day. A descriptive study in India [4] also resulted in online and blended learning similar to those in Indonesia and Bangladesh. These previous researches showed that students have not yet discovered the essence of online learning independently. Online learning has increased significantly since the pandemic. The increase in the number of online conference users reached $253 \%$ from March 2020 to June 2021 [5].

One of the factors driving online learning to become more meaningful is the student's willingness to learn collaboratively in online learning situations. Previous research showed a moderate positive correlation between students' attitudes toward collaborative learning and students' sense of community $(\mathrm{r}(198)=0.672, \mathrm{p}<.01) \quad[6]$. This research supported evaluative facts about the need for interaction in online learning. Collaborative learning becomes a bridge between students in online learning, which creates a sense of community. If this sense of community continues, students can be responsible or care about their learning community. Previous researchers also tried a collaborative online learning approach by involving a collaborative and online concept mapping tool. [7]. The research team also used OCLAS [8] to measure student attitudes towards the new approach [7]. The driving factor in asynchronous online learning also showed that the course structure positively affected both students' satisfaction and academic achievement. In addition, the strong relationship between student interactions with other students and the presence of an instructor has a positive effect on student engagement [9].

Educators need a valid and reliable tool to measure students' attitudes towards the application of online cooperative learning. The measurement results of this tool will later assist educators in evaluating the learning activities that have taken place. Online Cooperative Learning Attitude Scale (OCLAS) is an instrument to measure students' attitudes towards online cooperative learning [8]. Students can fill out this instrument independently (self-assessment) based on their own learning experiences. OCLAS has 17 items that measure students' positive and negative attitudes towards the implementation of online cooperative learning [8].

Online learning in Indonesia primarily uses Indonesian as the language of instruction. Therefore, educators in Indonesia need measuring tools to measure students' attitudes towards online cooperative learning. Furthermore, using instruments with different source languages and cultural contexts requires cultural adaptation and translation [10]. Therefore, the translation of OCLAS into the Indonesian language is crucial. Furthermore, this instrument helps improve the quality of cooperative online learning and students' performance in online learning.

Based on the explanation above, this research aims to validate and determine the reliability of OCLAS in the Indonesian language. Furthermore, adapting and validating OCLAS in Indonesian and testing students' attitudes towards cooperative online learning will contribute to the main objective.

\section{METHOD}

This research is a quantitative research to adapt the Online Cooperative Learning Attitude Scale (OCLAS) [8] into the Indonesian language. The first step in the process of adapting the measuring instrument is translating the measuring instrument into Indonesian. Then, we retranslated (back translation) the Indonesian version to English to test the translation's consistency. Indonesian language experts carried out the translation process at a reputable University's Language Center. After the translation process, the Indonesian language OCLAS was tested on the research sample.

The population of this study were college students and high school students. The selection process utilized the measuring instrument's characteristics that aim to measure the assessment of educators and educational institutions related to the 
development of online learning. Based on data from the Central Statistics Agency [11], researchers found the number of high school students in Indonesia was around 4.8 million people. Data for the number of students is around 7.3 million people [12]. Bartlett, Kotrlik, and Higgins [13] explained that if the population is more than 10,000 , the researcher could take a minimum sample of 119. Based on the population range and the theory, the number of participants in this study was 334, with the status of college students and high school students currently conducting online learning in their respective residences.

\section{OCLAS Instrument}

Researchers used the OCLAS [8] to measure the attitudes of college students and high school students in online learning. OCLAS provides an overview of students' attitudes and abilities in dealing with online learning environments [8].

OCLAS is a measuring instrument in a Likert scale with a scale of one to five and contains 17 items. On each item, participants should choose from a scale of one (never) to five (always). An example of an OCLAS item is "Saya menikmati pengalaman belajar kooperatif melalui ABKD bersama anggota kelompok saya". Table 1 showed the results of the translation of OCLAS into Indonesian.

To seek validity, we utilized the Corrected item-total Correlation technique to determine each item's validity. In addition, we used the Cronbach's Alpha coefficient technique to determine the reliability of the OCLAS measuring instrument.

Table 1. Original and Indonesian Version of OCLAS

\begin{tabular}{cll}
\hline Items & OCLAS Original & OCLAS-Indonesian \\
\hline 1 & I enjoy solving & Saya senang \\
& problems & menyelesaikan \\
& regarding the & masalah yang terkait \\
& group project & dengan tugas \\
& using Online & kelompok saya \\
& Learning & bersama anggota \\
& Application & lainnya melalui \\
& (OCLA) with my & Aplikasi Belajar \\
& group member. & Kooperatif Daring \\
\hline
\end{tabular}

\begin{tabular}{|c|c|c|}
\hline Items & OCLAS Original & OCLAS-Indonesian \\
\hline & & $(A B K D)$ \\
\hline 2 & $\begin{array}{l}\text { Being interactive } \\
\text { with the other } \\
\text { group members } \\
\text { using OCLA } \\
\text { increases my } \\
\text { motivation for } \\
\text { learning. }\end{array}$ & $\begin{array}{l}\text { Berinteraksi dengan } \\
\text { anggota kelompok } \\
\text { lainnya melalui } \\
\text { ABKD meningkatkan } \\
\text { motivasi belajar } \\
\text { saya. }\end{array}$ \\
\hline 3 & $\begin{array}{l}\text { I enjoy } \\
\text { experiencing } \\
\text { cooperative } \\
\text { learning using } \\
\text { OCLA with my } \\
\text { group members. }\end{array}$ & $\begin{array}{l}\text { Saya menikmati } \\
\text { pengalaman belajar } \\
\text { kooperatif melalui } \\
\text { ABKD bersama } \\
\text { anggota kelompok } \\
\text { saya. }\end{array}$ \\
\hline 4 & $\begin{array}{l}\text { Online group } \\
\text { activity increases } \\
\text { our creativity. }\end{array}$ & $\begin{array}{l}\text { Kegiatan kelompok } \\
\text { secara daring } \\
\text { meningkatkan } \\
\text { kreativitas kami. }\end{array}$ \\
\hline 5 & $\begin{array}{l}\text { I believe that the } \\
\text { group can work } \\
\text { on a document } \\
\text { effectively with } \\
\text { the online } \\
\text { cooperative } \\
\text { learning } \\
\text { applications. }\end{array}$ & $\begin{array}{l}\text { Saya yakin dengan } \\
\text { kemampuan } \\
\text { kelompok saya untuk } \\
\text { mengerjakan sebuah } \\
\text { dokumen secara } \\
\text { efektif dengan } \\
\text { bantuan ABKD. }\end{array}$ \\
\hline 6 & $\begin{array}{l}\text { OCLA improves } \\
\text { my social skills. }\end{array}$ & $\begin{array}{l}\text { ABKD meningkatkan } \\
\text { kemampuan sosial } \\
\text { saya. }\end{array}$ \\
\hline 7 & $\begin{array}{l}\text { I enjoy helping } \\
\text { others in OCLA. }\end{array}$ & $\begin{array}{l}\text { Saya senang } \\
\text { membantu orang lain } \\
\text { dalam } A B K D .\end{array}$ \\
\hline 8 & $\begin{array}{l}\text { OCLA is very } \\
\text { entertaining for } \\
\text { me. }\end{array}$ & $\begin{array}{l}\text { Bagi saya, } A B K D \\
\text { sangat } \\
\text { menyenangkan. }\end{array}$ \\
\hline 9 & $\begin{array}{l}\text { OCLA helps me } \\
\text { feel better } \\
\text { psychologically. }\end{array}$ & $\begin{array}{l}\text { ABKD membantu } \\
\text { saya merasa lebih } \\
\text { baik secara } \\
\text { psikologis. }\end{array}$ \\
\hline 10 & $\begin{array}{l}\text { More ideas come } \\
\text { up as a result of } \\
\text { OCLA. }\end{array}$ & $\begin{array}{l}\text { Semakin banyak ide } \\
\text { yang muncul berkat } \\
\text { ABKD. }\end{array}$ \\
\hline 11 & $\begin{array}{l}\text { I think that I have } \\
\text { had/will have } \\
\text { more successful } \\
\text { results since I } \\
\text { work with a group } \\
\text { in OCLA. }\end{array}$ & $\begin{array}{l}\text { Saya merasa saya } \\
\text { sudah/akan mencapai } \\
\text { hasil yang baik sejak } \\
\text { saya bekerja dalam } \\
\text { kelompok melalui } \\
\text { ABKD. }\end{array}$ \\
\hline 12 & $\begin{array}{l}\text { Trying to teach } \\
\text { something to my } \\
\text { group members in } \\
\text { OCLA makes me } \\
\text { tired. }\end{array}$ & $\begin{array}{l}\text { Mengajarkan } \\
\text { anggota kelompok } \\
\text { saya dalam ABKD } \\
\text { membuat saya lelah. }\end{array}$ \\
\hline 13 & $\begin{array}{l}\text { OCLA does not } \\
\text { make any sense to } \\
\text { me. }\end{array}$ & $\begin{array}{l}\text { ABKD tidak masuk } \\
\text { akal bagi saya. }\end{array}$ \\
\hline 14 & $\begin{array}{l}\text { I cannot develop } \\
\text { my ideas in }\end{array}$ & $\begin{array}{l}\text { Saya tidak bisa } \\
\text { mengembangkan ide }\end{array}$ \\
\hline
\end{tabular}




\begin{tabular}{|c|c|c|}
\hline Items & OCLAS Original & OCLAS-Indonesian \\
\hline & OCLA & $\begin{array}{l}\text { saya sendiri dalam } \\
A B K D .\end{array}$ \\
\hline 15 & $\begin{array}{l}\text { I don't like that } \\
\text { people are } \\
\text { depending on me } \\
\text { in OCLA. }\end{array}$ & $\begin{array}{l}\text { Saya merasa tidak } \\
\text { nyaman ketika orang } \\
\text { lain bergantung pada } \\
\text { saya dalam ABKD. }\end{array}$ \\
\hline 16 & $\begin{array}{l}\text { I don't think that } \\
\text { my interaction } \\
\text { with my group } \\
\text { members in } \\
\text { OCLA will make } \\
\text { any contribution } \\
\text { to me. }\end{array}$ & $\begin{array}{l}\text { Saya merasa bahwa } \\
\text { interaksi saya dengan } \\
\text { anggota kelompok } \\
\text { saya dalam ABKD } \\
\text { tidak akan } \\
\text { memberikan manfaat } \\
\text { apapun bagi saya. }\end{array}$ \\
\hline 17 & $\begin{array}{l}\text { OCLA is not } \\
\text { suitable for me. }\end{array}$ & $\begin{array}{l}\text { ABKD tidak cocok } \\
\text { bagi saya }\end{array}$ \\
\hline
\end{tabular}

\section{RESULTS AND DISCUSSION}

\section{A. RESULT}

Researchers tested the validity of the Indonesian OCLAS using the corrected-item total correlation $\left(\mathrm{r}_{\mathrm{citc}}\right)$ technique. In this validity test, the correlation limit of 0.3 is considered to be valid. Sample for the validity test were the Pharmacy students, Non-Pharmaceutical students, and high school students.

The validity calculation produced a range of item correlations from -0.170 to 0.711 as shown in Table 2. For the group of Pharmacy students, items that were declared invalid were item number $1\left(r_{\text {citc }}=0.298\right)$, number $12\left(r_{\text {citc }}=0.294\right)$, number $13\left(r_{\text {citc }}=-0.059\right)$, number $14\left(r_{\text {citc }}=-0.052\right)$, number $15\left(r_{\text {citc }}=\right.$ $0.127)$, number $16\left(r_{\text {citc }}=0.173\right)$, and number $17\left(\mathrm{r}_{\text {citc }}=-0.106\right)$. In the Non-Pharmacy student group, the invalid items were item number $12\left(\mathrm{r}_{\text {citc }}=0.099\right)$, number $13\left(\mathrm{r}_{\text {citc }}=\right.$ $0.047)$, number $14\left(\mathrm{r}_{\mathrm{citc}}=0.075\right)$, number 15 $\left(r_{\text {citc }}=0.069\right)$, and number $17\left(r_{\text {citc }}=0.095\right)$. Meanwhile, in the group of high school students, the invalid items were item number $12\left(r_{\text {citc }}=0.124\right)$, number $13\left(r_{\text {citc }}=-0.027\right)$, number $14\left(\mathrm{r}_{\text {citc }}=0.012\right)$, number $15\left(\mathrm{r}_{\text {citc }}=\right.$ $0.061)$, number $16\left(r_{c i t c}=0.030\right)$, and number $17\left(r_{\text {citc }}=-0.170\right)$. Therefore we concluded that the Indonesian OCLAS would have ten items instead of 17 . We removed invalid items number 1, 12-17.
Table 2. OCLAS Validity Test Results

\begin{tabular}{|c|c|c|c|}
\hline Item & $\begin{array}{l}\text { Corrected } \\
\text { Item-Total } \\
\text { Correlation } \\
\text { Pharmacy }\end{array}$ & $\begin{array}{l}\text { Corrected } \\
\text { Item-Total } \\
\text { Correlation } \\
\text { Non- } \\
\text { Pharmacy }\end{array}$ & $\begin{array}{l}\text { Corrected } \\
\text { Item-Total } \\
\text { Correlation } \\
\text { SMA }\end{array}$ \\
\hline 1 & $0.298^{*}$ & 0.537 & 0.445 \\
\hline 2 & 0.422 & 0.342 & 0.524 \\
\hline 3 & 0.427 & 0.314 & 0.493 \\
\hline 4 & 0.497 & 0.624 & 0.494 \\
\hline 5 & 0.436 & 0.692 & 0.432 \\
\hline 6 & 0.488 & 0.372 & 0.462 \\
\hline 7 & 0.319 & 0.427 & 0.419 \\
\hline 8 & 0.388 & 0.599 & 0.453 \\
\hline 9 & 0.711 & 0.697 & 0.409 \\
\hline 10 & 0.498 & 0.691 & 0.460 \\
\hline 11 & 0.638 & 0.575 & 0.554 \\
\hline 12 & $0.294 *$ & $0.099 *$ & $0.124 *$ \\
\hline 13 & $-0.059 *$ & $0.047 *$ & $-0.027 *$ \\
\hline 14 & $-0.052 *$ & $0.075^{*}$ & $0.012 *$ \\
\hline 15 & $0.127 *$ & $0.069 *$ & $0.061 *$ \\
\hline 16 & $0.173 *$ & 0.348 & $0.030 *$ \\
\hline 17 & $-0.106^{*}$ & $0.095 *$ & $-0.170 *$ \\
\hline
\end{tabular}

* Items were invalid due to the $r_{\text {citc. }}$.

We conducted a reliability test using the Cronbach's alpha coefficient with a correlation coefficient value of 0.7 for the measuring instrument declared reliable. Table 3 showed the results of the OCLAS reliability test. The Indonesian OCLAS is a reliable measuring tool.

Table 3. OCLAS Reliability Test Results

\begin{tabular}{llll}
$\begin{array}{l}\text { Items } \\
\text { Total }\end{array}$ & Pharmacy & $\begin{array}{l}\text { Non- } \\
\text { Pharmacy }\end{array}$ & SMA \\
\hline 17 & 0.711 & 0.791 & 0.702 \\
\hline
\end{tabular}

\section{B. DISCUSSION}

In this study, our team has adapted OCLAS into Indonesian. OCLAS is useful in measuring students' attitudes towards online cooperative learning applications. Overall, OCLAS measures two factors, namely negative and positive students' attitudes towards OCLAS [8]. Items 1 through 11 assessed students' positive attitudes, while items 12 through 17 assess students' negative attitudes toward online cooperative learning.

We found that all items measuring negative attitudes (items 12-17) were invalid through validity correlation values. Number one was also invalid for the Pharmacy 
students. Therefore, we also excluded it. Based on the validation results, these ten items measured positive attitudes toward online cooperative learning. Scoring for Indonesian OCLAS ranged from 10 to 50 . The higher the score is the higher the attitudes toward online cooperative learning.

Researchers utilized the Cronbach alpha coefficient for reliability testing. According to psychometric rule, a measuring instrument is declared valid if its coefficient value is more than 0.7. Based on the reliability test results, the results were 0.711 for pharmacy students, 0.791 for non-pharmaceutical students, and 0.702 for high school students. Therefore, we concluded that the Indonesian version of OCLA is reliable because the coefficient value of the three groups was more than 0.7. Table 4 showed the Indonesian OCLAS after the validity and reliability test.

We can think of four things from the analysis of invalid items in numbers 12-17. First, participants found them difficult to fill in negative attitudes towards online cooperative learning. In Indonesia, online cooperative learning cannot create the wanted outcome. Participants felt ambiguous with the sudden change in learning methods to online learning during the COVID-19 pandemic [14]. The second analysis is the heterogeneity of internet access in Indonesia in terms of internet availability and speed. This caused a variety of students' opinions about online learning [15-17]. A similar study in Malaysia also revealed a similar thing [18]. The third was the heterogeneity of the use of online learning platforms in schools and colleges [19-21]. Schools and universities interpret online learning in various ways. Not all educational institutions utilized LMS. Online learning can include various ways; some used Whatsapp [21], social media [22], and some better arrangement institutions utilized the LMS platforms [23] Lastly, the difficulty of educators in conducting collaborative and cooperative online learning was another reason [24-26]. At the same time, access to training was also limited to online learning training, which is primarily one-way or with ineffective assistance. When participants answered or judged themselves on negative attitudes, especially regarding assistance for themselves and their class, of course, they were also very diverse. Likewise, about the level of self-comfort.

Ambiguity in the interpretation of the translation from English to Indonesian can be one of the reasons why statement number 13 is invalid [27]. Statement number 13 in Indonesian, "ABKD tidak masuk akal bagi saya". The phrase "tidak masuk akal" was confusing for respondents. The meaning association of "tidak masuk akal" in the Indonesian language was multiple. The meaning can mean irrational or crazy, mentally unhealthy, extraordinary, disturbed, too excessive. There are at least more than five meanings of the phrase. This measurement can lead to various interpretations. We propose that the translation of "OCLA does not make any sense to me" would be "Saya merasa ABKD adalah hal yang tidak terbayangkan sama sekali".

Item number 1 was an invalid item for the Pharmacy students' group. This is because pharmacy students' characteristics of assignments or teaching materials may be more effective with independent study than online group work. On the other hand, in non-pharmacy and high school students, this number one positive attitude statement was a valid item. However, to provide certainty, we have removed this item from the Indonesian OCLAS for the time being until further research.

Table 4. Indonesian OCLAS after the Validity and Reliability Test

\begin{tabular}{cl}
\hline Items & Indonesian-OCLAS \\
\hline 2 & $\begin{array}{l}\text { Berinteraksi dengan anggota } \\
\text { kelompok lainnya melalui Aplikasi } \\
\text { Belajar Kooperatif Daring (ABKD) } \\
\text { meningkatkan motivasi belajar saya. }\end{array}$ \\
\hline 3 & $\begin{array}{l}\text { Saya menikmati pengalaman belajar } \\
\text { kooperatif melalui ABKD bersama } \\
\text { anggota kelompok saya. }\end{array}$ \\
\hline 4 & Kegiatan kelompok secara daring \\
\hline
\end{tabular}




\begin{tabular}{cl}
\hline Items & Indonesian-OCLAS \\
\hline 5 & $\begin{array}{l}\text { meningkatkan kreativitas kami. } \\
\text { kelompok saya untuk mengerjakan } \\
\text { sebuah dokumen secara efektif } \\
\text { dengan bantuan ABKD. }\end{array}$ \\
\hline 6 & $\begin{array}{l}\text { ABKD meningkatkan kemampuan } \\
\text { sosial saya. }\end{array}$ \\
\hline 7 & $\begin{array}{l}\text { Saya senang membantu orang lain } \\
\text { dalam ABKD. }\end{array}$ \\
\hline 8 & $\begin{array}{l}\text { Bagi saya, ABKD sangat } \\
\text { menyenangkan. }\end{array}$ \\
\hline 9 & $\begin{array}{l}\text { ABKD membantu saya merasa lebih } \\
\text { baik secara psikologis. }\end{array}$ \\
\hline 10 & $\begin{array}{l}\text { Semakin banyak ide yang muncul } \\
\text { berkat ABKD. }\end{array}$ \\
\hline 11 & $\begin{array}{l}\text { Saya merasa saya sudah/akan } \\
\text { mencapai hasil yang baik sejak saya } \\
\text { bekerja dalam kelompok melalui } \\
\text { ABKD. }\end{array}$
\end{tabular}

\section{CONCLUSION}

The purpose of this research was to validate and determine the reliability of OCLAS-Indonesian. The Indonesian version of the OCLAS validation test showed ten valid and seven invalid items. In addition, this instrument also obtained a reliability test of 0.711 in pharmaceutical students, 0.791 in non-pharmaceutical students, and 0.702 in high school students. Therefore, the Indonesian version of OCLAS was reliable based on the test.

\section{REFERENCES}

[1] E. A. Humphrey and J. R. Wiles, Lessons Learned through Listening to Biology Students during a Transition to Online Learning in the Wake of the COVID-19 Pandemic, Ecol. Evol. 11, 3450 (2021).

[2] W. Buska, S. M. Munthalib, Nurhasnah, M. Elwidah, and Y. Prihartini, Analysis of Online Learning Activities During the COVID-19 Pandemic at Sulthan Thaha Saifuddin State Islamic University of Jambi, J. Phys.: Conf. Ser. 1779, 012023 (2021).

[3] R. Afroz, N. Islam, S. Rahman, and N. Zerin Anny, Students' and Teachers' Attitude towards Online Classes during Covid-19 Pandemic: A Study on Three
Bangladeshi Government Colleges, IJRBS 10, 462 (2021).

[4] R. Bordoloi, P. Das, and K. Das, Perception towards Online/Blended Learning at the Time of Covid-19 Pandemic: An Academic Analytics in the Indian Context, AAOUJ 16, 41 (2021).

[5] S. Chan, Usage of Mobile Video Conferencing Apps Including Zoom Grew 150\% in the First Half of 2021, https://sensortower.com/blog/videoconferencing-apps-mau-growth.

[6] R. Chatterjee and A.-P. Correia, Online Students' Attitudes Toward Collaborative Learning and Sense of Community, American Journal of Distance Education 34, 53 (2020).

[7] M. Farrokhnia, H. J. Pijeira-Díaz, O. Noroozi, and J. Hatami, ComputerSupported Collaborative Concept Mapping: The Effects of Different Instructional Designs on Conceptual Understanding and Knowledge CoConstruction, Computers \& Education 142, 103640 (2019).

[8] Ö. Korkmaz, A Validity and Reliability Study of the Online Cooperative Learning Attitude Scale (OCLAS), Computers \& Education 59, 1162 (2012).

[9] S. Kim and D.-J. Kim, Structural Relationship of Key Factors for Student Satisfaction and Achievement in Asynchronous Online Learning, Sustainability 13, 6734 (2021).

[10] D. E. Beaton, C. Bombardier, F. Guillemin, and M. B. Ferraz, Guidelines for the Process of CrossCultural Adaptation of Self-Report Measures, Spine 25, 3186 (2000).

[11] KataData, Berapa Jumlah Peserta Didik Indonesia?

Databoks, https://databoks.katadata.co.id/datapubl ish/2019/05/02/berapa-jumlah-pesertadidik-indonesia.

[12] A. Lidwina, Mahasiswa Indonesia Paling Banyak Jurusan Pendidikan dan Ekonomi | Databoks, https://databoks.katadata.co.id/datapubl 
ish/2021/02/15/mahasiswa-indonesiapaling-banyak-jurusan-pendidikan-danekonomi.

[13] J. E. Bartlett, J. W. Kotrlik, and C. C. Higgins, Organizational Research: Determining Appropriate Sample Size in Survey Research, Information Technology, Learning, and Performance Journal 19, 43 (2001).

[14] D. S. Bestiantono, P. Z. R. Agustina, and T.-H. Cheng, How Students' Perspectives about Online Learning Amid the COVID-19 Pandemic?, Stud. Learn. Teach. 1, 133 (2020).

[15] D. Jamaluddin, T. Ratnasih, H. Gunawan, and E. Paujiah, Pembelajaran Daring Masa Pandemik Covid-19 Pada Calon Guru: Hambatan, Solusi Dan Proyeksi, Lembaga Penelitian dan Pengabdian Kepada Masyarakat UIN Sunan Gunung Djati Bandung 10 (2020).

[16] U. Mulyawan, Problematika Online Learning; Hambatan Pembelajaran Bahasa Inggris Siswa, JIH 9, 301 (2021).

[17] D. Hariyanti, A. H. Mun'im, and N. Hidayat, Identifikasi Hambatan Mahasiswa dalam Pelaksanaan Pembelajaran Biologi Secara Daring Selama Pandemi Covid-19 di Kabupaten Jember, Alveoli: Jurnal Pendidikan Biologi 1, 11 (2020).

[18] E. Chung, N. M. Noor, and V. N. Mathew, Are You Ready? An Assessment of Online Learning Readiness among University Students, . International Journal of Academic Research in Progressive Education and Development 9, 18 (2020).

[19] Gunawan, N. M. Y. Suranti, and Fathoroni, Variations of Models and Learning Platforms for Prospective Teachers During the COVID-19 Pandemic Period, Indonesian Journal of Teacher Education 1, 61 (2020).

[20] M. Giatman, S. Siswati, and I. Y. Basri, Online Learning Quality Control in the Pandemic Covid-19 Era in Indonesia,
Journal of Nonformal Education 6, 168 (2020).

[21] H. Mulyono, G. Suryoputro, and S. R. Jamil, The Application of WhatsApp to Support Online Learning during the COVID-19 Pandemic in Indonesia, Heliyon 7, e07853 (2021).

[22] B. M. Ngussa, F. K. Fitriyah, and S. W. M. Diningrat, Correlation Between Facebook Use, Mental Health and Learning Engagement: A Case of Universities in Surabaya City, Indonesia, Turkish Online Journal of Distance Education 22, 229 (2020).

[23] Sriadhi, Khaerudin, N. Wahyuningtyas, Darni, R. Zainul, M. Adri, Rusdinal, Nasrun, Rahmulyani, Nuranjani, Nurmaniah, A. Wedi, E. Surahman, E. N. Aisyah, H. I. Oktaviani, R. S. M. Meilanie, S. N. Purnamawati, Hapidin, W. D. Listyasari, Irsyad, Syafril, Anisah, Y. Santoso, Muhardi, A. Kristanto, L. H. Susarno, D. Kuswandi, R. Wardani, and E. Adnan, Development of Moodle-Based Content Learning System in MKDK Student Development Subjects at LPTK in Indonesia, J. Phys.: Conf. Ser. 1594, 012021 (2020).

[24] Y. B. Hermanto and V. A. Srimulyani, The Challenges of Online Learning During the Covid-19 Pandemic, JPP 54, 46 (2021).

[25] R. Rasmitadila, R. R. Aliyyah, R. Rachmadtullah, A. Samsudin, E. Syaodih, M. Nurtanto, and A. R. S. Tambunan, The Perceptions of Primary School Teachers of Online Learning during the COVID-19 Pandemic Period: A Case Study in Indonesia, J Ethn Cult Stud 7, 90 (2020).

[26] A. E. P. Atmojo and A. Nugroho, EFL Classes Must Go Online! Teaching Activities and Challenges during COVID-19 Pandemic in Indonesia, Register J. 13, 49 (2020).

[27] V. Swami and D. Barron, Translation and Validation of Body Image Instruments: Challenges, Good Practice Guidelines, and Reporting 
Recommendations for Test Adaptation, Body Image 31, 204 (2019). 